\title{
Secular spirituality versus secular dualism: Towards postsecular holism as model for a natural theology
}

\author{
Cornel W du Toit \\ Institute for Theology and Missiology \\ University of South Africa
}

\begin{abstract}
The term "secular spirituality" is meant to convey the contemporary phenomenon of spirituality as experienced in different spheres not associated with structured, institutionalised religion. An outline is given of the relation between secular reality (the natural realm) and religious/spiritual reality (the supernatural realm), as it developed from pre-secular animism (pre-modern unity with nature) to secular dualism (modernism) to post-secular holism (influence of postmodernism). Then follows a brief discussion of secular spirituality in Africa with reference to struggle spirituality. Secular spirituality in its technospiritual mode is becoming increasingly important and is dealt with cursorily before dealing with secular spirituality as a model for a postmodern natural theology. In this context "natural theology" is not concerned with proofs of God's existence, but seeks to integrate the natural and supernatural dimensions of human life meaningfully.
\end{abstract}

\section{INTRODUCTION}

The term "spirituality" can mean anything from a profound spiritual experience to an aesthetic experience; or it can simply fulfil a rhetorical function as an adjective or adverb. It may also be used metonymically to signify a sense of ecstasy, self-transcendence/joy/growth/renewal; unity; profound meaning; insight; religious experience, and the like. McGrath (1999:2) defines it thus: "Spirituality concerns the quest for a fulfilled and authentic life, involving the bringing together of the ideas distinctive of ... [some] religion and the whole experience of living on the basis of and within the scope of that religion." We shall use the term in light of this definition. 


\subsection{Rediscovering spirituality?}

The revival of spirituality is a result, not of some sort of religious awakening, but of developments in the prevailing worldview. ${ }^{1}$ The concept of spirituality cannot be understood in isolation: it needs to be related to the worldview and spirit of the times. Spirituality experienced in a world of phantoms and magic, gods and demons where humans are at the mercy of forces they cannot control is very different from spirituality experienced in a technoscientific world in which nature has been domesticated - a world in which the magic of progress has turned into nightmare, a runaway train that can no longer be stopped.

The escalating use of the term "spirituality"2 is symptomatic of the experiential impoverishment of modern people. Modern institutionalised life has become so predictable that any experience that touches the individual is called spiritual. This permits a proliferation of spiritual experiences, which has restored people's sense of transcendence. ${ }^{3}$ The experiences are limitless: any experience can acquire spiritual dimensions. The New Age movement offers plenty of secular experiences of this kind; there is the experience of technospirituality; the defiant experience of struggle spirituality during South Africa's liberation struggle; the experience of aesthetic spirituality that unites aficionados in a sensory eucharist of sound, form and colour. Spiritual experience comes from reading a novel or watching a movie that takes one into a mind-broadening world of new meanings and broad new vistas. Friendships, comradeship, nature are experienced spiritually. Sex, illness, travel - just about any human experience - can affect us in ways that we interpret as spiritual. Rhetorically this is expressed in statements like: "a spiritually and gastronomically sublime meal"; "South Africa lacks a spiritual sense of national unity"; "my holiday in the Seychelles was a spiritual pilgrimage." In such contexts it is not inappropriate to speak of spiritual secularity.

\footnotetext{
${ }^{1}$ The contemporary worldview is not readily subsumed under a few common denominators, because experience varies with the context in which it originates. First World worldviews differ dramatically from Third World worldviews. Holland (1988:42) sees the cardinal problems in the Third World as economic - the suffering of the poor; in the Second World the accent is on lack of freedom; and in the First World it centres on a cultural crisis (precisely what modernism is about: a crisis of progress). The point is that spirituality should be seen as closely related to the cardinal problems that preoccupy a culture. In every context worldview should be connected with that problem.

${ }^{2}$ Although the flood of literature on the subject is largely theological, the revival of spirituality probably originated in the "secular" sphere, whereupon it galvanised the churches into reclaiming their "spiritual property".

${ }^{3}$ The advantage of the term "spirituality" in a religious context is that it does not discriminate between religion and denomination, or between believers and unbelievers. It is a human capacity accessible to all.
} 
But do spiritual experiences of this nature mean that the person is a religious believer? Is secular spirituality religion? Is spirituality not simply a technology of the human self? One hallmark of authentic religion has always been that human beings do not determine either God or fate but have to wait on God. If spirituality is no more than a technology applied for the sake of experiential stimulation, we shall end up disenchanted.

Spirituality, then, is not a phenomenon in itself. It cannot be guaranteed a priori but usually features a posteriori when describing encounters, events and experiences. It is not a new kind of religion. But then, it does not profess to be, although some New Age groups display religious traits. ${ }^{4}$ Yet it is reductive to associate spirituality with practising adherents of traditional religions and secular spirituality with non-practitioners of these faiths. ${ }^{5}$

Secular spirituality, being the potential of all experience to assume a spiritual dimension, affects everyone. It is not confined to the religious or transcendent sphere but characterises the profane, secular life world. Whereas the medieval world was arranged around the church (profanum is the forecourt of the temple), today the church takes its cue from the world. The Christian church plays hardly any role in modern societies. Its role has been taken over by secular actors, such as the press, interest groups, certain laws, corporate values and ethics, and the human rights culture. Caiazza (2005: 12) writes: "The present state of affairs in Western culture is that religion as part of civil discourse is in retreat even in debates in which a religious perspective would be most helpful ... ."6

\subsection{From pre-secular animism to secular dualism to post-secular holism}

\subsubsection{Pre-secular animism}

In animist (typically primal) religions God, non-human nature and human beings are interlinked. The world is animated, enchanted and God is to be

\footnotetext{
${ }^{4}$ Collins (1999:106-113) lists the diverse sources on which New Age spirituality relies: "quantum physics, astrology, Celtic druidism, alchemy, spiritualism, Eastern religions, the occult, native American religion, witchcraft and animism."

${ }^{5}$ Langdon Gilkey"s secular theology seeks to demonstrate hermeneutically the religious substratum of secular culture on the basis of Tillich"s thesis that "culture is the form of religion and religion the substance of culture" (see Peters 2005:851).

${ }^{6}$ A number of complex factors contributed to this. They include the following: recognition of the plurality and equality of religions with differing claims; the specification (and relative restriction to the private domain) of religious rights in many constitutions; the exclusion of religious influence through constitutional entrenchment and implementation of human rights; the media"s use of ethical issues to form public opinion; the establishment of global democracy with fairly similar values; globalism; and the role of the World Court.
} 
seen - and feared - everywhere. This is known as the mythical or premodern phase. As culture developed humans, nature and gods were separated, and God and nature became objects of human contemplation. This was the "substantialist" phase or modernism. In our present, post-secular era human beings, god and world are once more connected. This is expressed in postmodern holism, the context in which the term "secular spirituality" should be understood.

In the pre-secular animist phase our forebears experienced intense emotions, which form the substratum of our spiritual experience: wonderment at the mystique of nature; fear of the unknown - the future, death and the inexplicability of birth and growth; reverence for the world soul ${ }^{7}$ exuded by everything. At the same time trust in, and union with, nature and the gods, to whom humankind owed its survival, must have helped to instil the sense of security and belonging that are fundamental to spirituality.

The pre-secular animist mind did not differentiate between natural and supernatural and there were no dualistic distinctions between nature and gods, nature and humankind or humans and gods. The world was experienced holistically and harmony and disharmony, life and death, the comprehensible and the incomprehensible were kept in equilibrium.

Some sort of animistic wholeness is resurfacing in the present search for meaning in nature. Contemporary myths and religions remain major vehicles of that meaning. In his Chance and necessity Jacques Monod refers to myths and religions which served and motivated humankind for a hundred thousand years since the time of its origins up to the scientific revolution. That revolution "ended the ancient animist covenant between man and nature, leaving nothing in place of that precious bond but an anxious quest in a world of icy solitude". Within three centuries, science, founded on the postulate of objectivity, has secured its place in society - in people's practice, but not in their hearts (quoted in Miller 1995:156).

\subsubsection{Secular dualism (modernism)}

The five centuries since the start of the scientific revolution - the modernist era - were characterised by growing secularism. It was a period of scientific awakening, marked by dissection and separation. Separation entailed the following: mind from matter (the Middle Ages still clung to the Aristotelian

\footnotetext{
${ }^{7}$ World soul (Lat anima mundi), denotes a universal spirit or soul that functions as an organizing principle. Plato used the concept of "word soul" to denote a spiritual principle, intelligence, or mind, harmony, proportion, and relatedness between the part and the whole, present in the world's body. World soul, held the same relation to the world as the human soul did to the body. The idea become obsolete with the rise of the mechanistic worldview of the Scientific Revolution.
} 
world soul that animated everything); science from theology; church from world; natural from supernatural; physical sciences from human sciences; scientific from unscientific; and so on. Along with these divisions dualism became entrenched in Western culture. The discovery of reason and the accent on rationalism, which came with Descartes, and the concomitant separation of intellect and matter (res cognitas versus res extensa) ran through Enlightenment culture like a golden thread. ${ }^{8}$

With the rise of Cartesianism the medieval feudal order crumbled. Industrialism led to increasing urbanisation, establishing the typically individualistic culture of modernism that underpins secularism (see Du Toit 2004:4-6, 13-15). A hallmark of many expressions of First World spirituality these days is their individualistic orientation: spiritual experience is an end in itself for the benefit of the individual. Grassow (1991:53) observes: "The spiritual experience was never an end in itself ... Any spirituality that does not produce service is false." African spirituality, by contrast, is not concerned with personal sensation or fulfilment. It is ideally communitarian, experienced in identification with the lot of the poor and the struggle of the oppressed (see Worsnip \& Van der Water 1991).

The term "secularisation" (Latin saeculum, lit: generation, age) originally referred to state confiscation of ecclesiastic property. In a religious context it relates to the erosion of religious traditions and an exodus from the churches. It may also connote theological developments which, in confrontation with tradition, curtail the absolute power of church dogma and especially the doctrine of revelation (the Bible). The common denominator is alienation, which lies at the root of secularisation.

Wiersenga (1992:75) sees secularisation as a process in which all areas of life and thought are freed from the influence of any form of metaphysics, including religion. In other words, it is a process in which "secular" thought is emancipated (alienated) from the ecclesiastic tyranny of the Middle Ages. For the first thirteen centuries after the establishment of Christianity secularism was not a factor worth considering (Raman 2005b:

\footnotetext{
${ }^{8}$ Cartesian mind-body dualism inspired many other dualisms, including the sacred-secular distinction as we came to know it. The theology of that time generously accommodated this: the soul resided in the mind, was indestructible and eternal, while the body or flesh harboured human desires and sin. Life on earth was just a portal to real life in heaven, where eternal bliss free from bodily constraints awaited the faithful. "True" believers were aliens on earth, destined to find their real home hereafter. The implication was that humans can do little to change the world, earthly pleasures are mostly sinful and to be avoided, and social injustice and political corruption are part of this dispensation.
} 
824) and its short history, coinciding with the scientific revolution, ${ }^{9}$ is astounding.

Theologically secularisation is to some extent associated with the notion of humankind's coming of age, which in Bonhoeffer's work summons people to live as if God is not a given. It implies that people take responsibility for themselves and their world rather than passively dismiss events as "God's will". ${ }^{10}$

Thus secularisation is the emancipation of the sciences, especially the natural science, from religious and metaphysical dependence. Hence it refers to the sciences' autonomy from the church and religion, their authority deriving from an independent theory of science, methodology and terminology, as distinct from ecclesiastic and religious pronouncements in areas applicable to their disciplinary field. Indeed, the sciences came to base their authority on their own bible (book of nature), as explained in Kepler's metaphor of two books (the book of God and the book of nature). The "two books"-metaphor, as well as all the dualisms to which it gave rise, eventually succumbed to the postmodern reintegration of reality, because dualism "depended upon supernaturalism for its intelligibility" (Griffin 2000:29).

At the same time the 17th century saw various attempts to harmonise religion, science and philosophy. As Funkenstein (in Bronislaw 2005:817) puts it, "the work of Galileo, Descartes, Newton, and Leibniz can be seen as a high point of convergence between science, philosophy and theology". The subsequent parting of the ways (of physical science and religion) should be viewed in light of the logical and methodological problem of reconciling nature and supernature in a scientific discipline. Nonetheless such a process was initiated in the 17th century with a shift in emphasis to the autonomy of nature: nature had to be explained in its own terms. The locus of authority in the sciences is the saeculum - the world of nature - rather than the world of revelation and faith (McGrath, 2001:100). The early mechanistic worldview of Newton's time subordinated nature to "both the human soul and the Divine Creator. It was adopted precisely to protect God and the soul - a motive that disappeared from the mechanistic view of the nineteenth century" (Griffin

\footnotetext{
${ }^{9}$ The Copernican revolution of the 15th century was perpetuated by, inter alia, the Enlightenment and the French and American political revolutions.

${ }^{10}$ On the whole theologians showed little tolerance for human autonomy. Thus Pannenberg (1988:47-58) is condemnatory of what he sees as theology's excessive assimilation of modern secular culture. As examples of such theologies he cites "God is dead" theology, demythologising theology, feminist theology and liberation theology.
} 
2000:27, 29-30). ${ }^{11}$ For a long time the supposition was that nature required a transcendent ground to explain its existence. This is not necessarily the case any more. To many nature is self-explanatory and self-explained (Crosby 2003:119).

In the context of secular dualism the distinctions between natural and supernatural, church and world, mind and body, and science and superstition became entrenched and, despite attempts to reconcile the poles, the overriding feeling was one of alienation. Cartesian rationalism accompanied and co-defined modernism, ${ }^{12}$ reaching a zenith in the late 19th century when it was curbed to some extent by postmodernism. Today we claim to have outgrown Cartesian mind-body dualism and to have rediscovered our bodily roots. Mind and rationality are rooted in bodily physicality (Wuketits); soul is not an entity existing independently of mind-body unity (Nancy Murphey); language and thought cannot develop without the human body and the very structure of language derives from our bodily movements and experience (Lakoff \& Johnson); religious experience is explained in terms of physical brain functions (Newberg; d'Aquili); the very structure of the human phenotype is genetically encoded and we are making headway in unravelling these codes, thus learning more about human nature and conduct. These are only a few of the factors that account for our present body culture, in which health and fitness, youth, food, beauty, longevity, entertainment and sensory experience are the main preoccupations. Religion and spirituality cannot remain unaffected: spirituality returns to corporeal spheres ${ }^{13}-$ those of the

\footnotetext{
${ }^{11}$ New cosmology, new physics and new biology can stimulate faith or provide grounds for unbelief. For some it is a spiritual experience to survey the world depicted by science over the last few decades. From new cosmology to new biology and cognitive science, one cannot but marvel at the many-splendoured wonder of life. Holmes Rolston III (1996: 411) describes it lyrically: "If anything at all on Earth is sacred, it must be this enthralling creativity that characterizes our home planet. If anywhere, here is the brooding Spirit of God. So the secular - this present, empirical epoch, this phenomenal world, studied by science - does not eliminate the sacred after all; to the contrary, it urges us on a spiritual quest." Others, by contrast, felt liberated by the story of new cosmology and experienced a gradual shift to a "different" worldview. Shermer (2004: 232) describes it happening in his own life as a systematic displacement of one worldview and way of thinking by another, "genesis and exodus myths by cosmology and evolution theories; faith by reason; final truths by provisional probabilities; trust by verification; authority by empiricism; and religious naturalism by scientific naturalism."
}

\footnotetext{
${ }^{12}$ Peterson's (2005:878) description of modernism is worth quoting in full: "Modernist thinking is mechanistic, atomistic, and consequently individualistic. Modernist thinking is given to totalizing metanarratives, seeking a unified truth that rejects pluralism and diversity. Modernistic thinking is reductionistic, especially in its scientific form. It is foundationalist and realist in its epistemology, often adhering to a correspondence theory of truth. It is ignorant of the way that questions of power, gender, and race affect putative claims to objectivity."

${ }^{13}$ Paradoxically, the whole notion of virtual reality and cyberspace represents the noncorporeal. Aupers \& Houtman (2005:82) cite the example of respondents who agreed on the spiritual significance of a disembodied presence in the virtual realm.
} 
human body, nature (extension of our physicality) and society (Holland 1988: 53).

Secularisation in the sense of scientific autonomy from ecclesiastic influence does not mean that all scientists have suddenly become atheists. Rather it indicates a realisation that there are questions and answers, problems and challenges that exist and need to be addressed without recourse to religion and the church. Our life world is bigger than the inner sanctum of the church and theology. Jackelén (2005:866-867) rightly views secularism as relating dialectically to religion, its "dancing partner or companion ... rather than its antagonist".

Acknowledgment of the interdependence of the physical and the metaphysical, of immanence and transcendence, is expressed in the term "post-secularism". It is a realisation that our destiny lies on this planet. We have rediscovered our earthly bounds. Soul is indivisibly part of body; mind and body are one. We are God's co-creators and we can do something about our earthly plight. To some extent the ideal of God's kingdom can be realised on earth. Neither the secular nor the spiritual side of our lives can be ignored: both need to be explained, structured and interpreted. We have to take responsibility for human nature, come to terms with it and accommodate it. This brings us to post-secular holism.

\subsubsection{Post-secular holism (postmodernism)}

The renewed stirrings of spirituality are a feature of the late 20th and early 21st century. To quote Glynn (1997: 139): "Such is the great surprise as the twentieth century turns into the twenty first: the very logic of human inquiry is compelling a rediscovery of the realm of spirit, of God and the soul." Postsecular does not mean reverting to a situation in which religion reigns supreme, but that both the church and the world have expanded their realms to accommodate changing cultural factors and social contexts. Secular spirituality does not mean that religious practice has passed from the church's hands to the worldly domain, or that the church has become superannuated. ${ }^{14}$ But what has happened in Western Christian churches is that the role of dogma, creed and council has declined and changed. This should be seen as a natural evolution that occurs in all human activities. Thus it affects not only ecclesiastic doctrines but also the technosciences - "a shift occurring within both religion and the technical sciences, away from impersonal canonical meanings and toward indexical, pragmatic solutions" (Bronislaw 2005:819).

\footnotetext{
${ }^{14}$ Indeed, secularism (with the accent on rationality, disciplinary autonomy and scientific integrity) occurred within the Christian church itself via theological developments like historical criticism, textual criticism, literary and redaction criticism, and hermeneutics. With reference to the influence of physics Caiazza (2005:17) rightly observes: "The success of secularism is based on the effects of technological advance rather than on the victory of scientific ideas in the conflict with religious belief."
} 
In Bonhoeffer's sense secular spiritual people have come of age and are exercising their own choices - without adopting a condescending attitude towards religious values. God and humankind, science and religion, humans and nature must be viewed as a stereoscopic whole. "Secularism in the modern world," says Raman (2005:3), "is not a rejection of religion, nor the denial of religious rights. It is rather a framework in which every citizen can exercise his or her chosen mode of spiritual fulfilment, whether traditional or modern, theistic, pantheistic, or atheistic; and where the laws of the land will not be dictated by the rules set forth in any particular holy book."

In postmodernism religion is democratised and gods have to make room for each other. Gods are both mediated and threatened by the technological creativeness of human beings. ${ }^{15}$ God concepts change as the notion of humans as images of God changes. Today human beings as images of God are understood against the background of human rights and dignity; God's image as described in divine revelation is expounded by science in the terminology of genetic mapping, cognitive science and socio-biology.

Postmodernism has questioned facile distinctions between natural and supernatural, science and faith; physical and metaphysical; assumption and proof. So far its questions and its challenge to science have not been answered satisfactorily (Raman 2005:825). The postmodern challenge concerns scientific method and notions of truth. Developments in physical science have added a metaphysical dimension. Caiazza (2005:13) puts it thus: "It seems that physics, the base science, can no longer give us visually precise pictures of either the atom, with its myriads attendant particles and intermingling forces, or outer space, now filled with waves of gravity, black holes, and dark matter." Gone are the days of knockdown arguments. Most 19th century physicists assumed that concepts like "God", "supernatural" and "miracle" were metaphysical, while things like space, force and matter were real. Whitworth (2003:202) reminds us of Mach, "who argued that "matter" is metaphysical, a mental construct which allows us economically to describe the persistence of certain clusters of sense impressions. The concept of "force", as in "the force of gravity", is metaphysical: it allows us to attribute a property to inanimate bodies by analogy with our own experience; it is convenient to think of the earth "attracting" smaller bodies, but it is not necessarily true."

Post-secular holism does not abrogate the distinction between natural and supernatural but, via the postmodernist idiom, indicates that interdependence at all levels is greater than we like to admit. Griffin (1988:17) puts it thus: "By recovering a vision of deity in which norms and values can

\footnotetext{
${ }^{15}$ Technology (and, via technology, human beings) is assuming attributes analogous to those of omnipresence, omnipotence, omniscience and eternal life, which were once ascribed exclusively to God's incommunicable attributes.
} 
have a natural abode, and by affirming a nonsensory level of perception through which such norms can be perceived, postmodern spirituality overcomes the complete relativism which followed from modernity's disenchantment of the world."

Philip Hefner (2003:193) quotes Ewert Cousins who compares our age to the Second Axial Age in respect of the following characteristics: (1) a complex process of convergence that transforms the earlier move toward differentiation, without abolishing differences; (2) a spirituality of the earth that celebrates our roots in the natural world; (3) the recovery of the view of primal peoples that the entire human race is one tribe; (4) a turning towards the material world as the locus of spiritual reality, placing real-world global problems on the spiritual agenda; and (5) dialogical cooperation between the world religions in efforts to deal with these real-world problems, most notably peace, justice, poverty, discrimination and care of the earth.

\section{AFRICAN SPIRITUALITY: A "SECULAR" SPIRITUALITY?}

Without romanticising African religion, the following comments (albeit generic and oversimplified) seem justified:

- African thought is holistic. It was never subjected to Cartesian mindbody dualism. "For the most part when they (Africans) looked upon the cosmos they saw Man, Nature and God as a unity; distinct but inseparable aspects of a sacred whole" (Paris 1995:35).

- African cosmologies share one primary feature: their belief in a sacred cosmos created and preserved by a supreme deity. The three realms of reality (spirit, history and nature) are deeply rooted in mythologies and cosmologies (Paris 1995:34).

- African religion is an example of a worldly religion with a secular spirituality. Its spirituality has always been bodily.

- Naturalism is not foreign to Africa, although the interrelatedness and interaction with nature should not be understood in the Western sense.

- African religion promises to be a stimulating dialogue partner for postmodern theology.

African spirituality is a spirituality of the marketplace, not housed in a church. Because African religion never acquired a temple tradition (with its concomitant preservation of holy scriptures and sacred truths), it makes no 
distinction between church and world, between sacred and profane. As a result Africa did not experience the crisis of modernism and the ensuing dualisms. The involvement of the supernatural (God and ancestors) in people's daily activities and vicissitudes is taken for granted. Technoscience is there to serve human beings, not the other way round. African spirituality is thus not an isolated phenomenon restricted to the "religious" part of their lives but encompasses the daily trials and tribulations.

Let us briefly consider "struggle spirituality" as an example of African secular spirituality (Worsnip \& Van der Water 1991). ${ }^{16}$ Struggle spirituality was collective -something individualistic modernists find hard to grasp. It was characterised by a spirit that united and motivated black people collectively, a secular spirituality because it was experienced as spiritual in this world - a world where oppression prevailed and a will to freedom was alive.

Although secularism does not pose a problem in Africa, most African countries experience it as a threat to African culture and tradition. Growing urbanisation and exposure to the market economy with its values of selfenrichment and individualism are alienating people from tribal traditions. Cosmopolitanism is superseding ethnic customs, traditional rites and African communitarianism (cf the ubuntu model).

Struggle spirituality was born of the struggle against poverty and political oppression, in which mutual dependence created a remarkable solidarity and unity, expressed in the ubuntu concept of "caring and sharing". In this respect struggle spirituality strongly resembles the spirituality, born of circumstances and lifestyle, of the early churches described in the New Testament book of Acts

\section{SECULAR SPIRITUALITY AS TECHNO-SPIRITUALITY}

Technological artefacts are processed nature. Modern life is inconceivable without them, prosthetically extending our bodies and forming an important part of our self-image. Nature's artistry is technology that evolved successfully over millions of years - technology which human beings learned in a much shorter time and promptly copied. Technology brings nature close to us and represents our tangible relationship with nature. In its virtual form it is increasingly influencing our anthropology. It assumes religious, even mystical

\footnotetext{
${ }^{16}$ Religious fanaticism may also be regarded as a form of secular spirituality. Such groups tend to split off from the moderation of mainline traditions and link religion to political ideals. The difference between the spirituality of freedom fighters and that of religious fanatics is complex and calls for hermeneutic inquiry. In this regard Pannenberg (1988:31) cites Berger's diagnosis: "The resistance to the secular culture of the West in Third World countries has found its most viable end effective expression in the revival of a fundamentalist and militant Islam."
} 
features and has become the determinant of our hopes, well-being, peace and eschatology. Present day natural theology grapples with nature in its technological mode which confronts us with issues that can be typified as ecumenical, interreligious and intercultural in nature. In our time technology has become the primary force that threatens to realise eschatology catastrophically. In this sense all people are daily grappling with a global natural theology and its ethical implications.

When we talk about nature, natural theology, nature spirituality and the like we mean more than pristine nature. These notions include something of our understanding of the physical vastness, the cosmological history of the universe; our understanding of humankind written by nature over many millennia - microcosm reflecting the grandeur, beauty and complexity of the macrocosm. More specifically, it is nature invisible to the human eye. This is nature fraught with an intensely sacred dimension when we, its co-creators, take its blueprint in hand and are faced with the question: "What is humankind?"

Technology is par excellence the cultural artefact of our time, a product of the nature that humans have domesticated. ${ }^{17}$ Traditionally technology was secular: it related to humankind as homo faber, could be bought, taught, upgraded and replaced. In classical Greek the term "techne" referred to art, that which characterises a craftsman's work. To many religious people technology was an alienating force, "the encapsulation of human rationality" that offered a means of combating religion and superstition (Aupers \& Houtman 2005:81). Hence the spiritual dimension assigned to technology is a recent development.

As the antithesis of techno-spirituality one could posit technosecularism, indicating that technological development is not dependent on, or sensitive to, religion. Caiazza sees the ethic of techno-secularism as the utilitarian highest good for the greatest number. This view is instrumentalist and materialistic. Techno-secularism would welcome the erosion of the dogmatic dimension of religion in order to put religion's ability to change people's lives and launch social movements to pragmatic use (Caiazza 2005:20).

\footnotetext{
${ }^{17}$ The religions of the book installed God in a temple and domesticated him; they put him in a library where he could be read; they put him in lecture halls and made him a debating point. But God is spirit, as early nomadic tribes experienced, and as spirit he travels with us. He does not belong in a temple - see Solomon's discourse at the dedication of the temple, when he acknowledged that no temple can ever contain God (1 Ki 8:27). Religion's "domestication" of God went hand in hand with the domestication of nature. We made nature our object, described it and conquered it. We shamelessly "plagiarise" its intellectual property that took millions of years to evolve and convert that knowledge into technology, which we use to the detriment of nature for the benefit of our own convenience.
} 
Technology, like human beings, readily displays a banal side. That is because it is a mirror image of human beings, with all the human attributes of self-indulgence, indolence, lust for power, vanity and ostentation. Hence technology is never neutral.

Everyone knows that few people understand the technology they use and the science on which it is based. Gone are the days when ordinary folk could take technological gadgets apart, understand them, piece them together again - and find they still work! Technology has been taken away from ordinary people, just as Latin prevented medieval Christians from reading the Bible for themselves, and as Galileo's "book of nature" at the start of the scientific revolution was written in mathematics, thus making science inaccessible to lay people. That is why technology today has a mystical character for many people. "Technology is thought of as mysterious not simply because of ignorance but because it is mysterious" (Bronislaw 2005:819). Its mystical character stems from its inaccessibility and, like anything we do not understand, our expectations may far exceed its capacity. This gives technology an eschatological dimension: we blindly believe that in future crises we will produce the technology to save the day. Like miracles, the power of technology is limitless.

Jacques Ellul (in Raman 2005a:828) describes his technological pessimism thus: "Nothing belongs any longer to the realm of the gods or supernatural. The individual who lives in the technical milieu knows well that there is nothing spiritual anywhere. But man cannot live without the sacred. He therefore transfers his sense of the sacred to the very thing which has destroyed its former object: to ... [technology] itself." Ellul wrote this in 1964. Whereas the 1960s and 1970s were anti-technology, the current "attribution of spiritual meaning to the digital realm" represents a remarkable change (Aupers \& Houtman 2005:85). Technology can in fact act as a surrogate for religion. Newman (1997:110-111) comments: “Technology's very success in contributing to the realization of ideals such as freedom, knowledge, happiness, and peace ... may lead the practical observer to believe that technology is a proper successor to religion." To Roy (2005:841) technoscience is "the cathedral of our culture".

For all these reasons technology is ambivalent. It can liberate and enslave. Human beings have become objects in a world where technoscience is the subject. Georg Simmel (quoted by Armstrong 2003:168-170) depicts technological society as ultimately evacuating the subject and colonising the waste spaces of the self for capital. The machine becomes the surrogate for human beings, living on their behalf. Technology is "not simply ... a matter of 
devices or even techniques, but central to the notions of the human - and to thinking itself" (Armstrong 2003:176).

Considering all this, how is techno-spirituality possible? Jackelén (2005:869) explains the dependence of religion on technology as follows: "Throughout their history, religions have made use of technology in the widest sense. Meditation, fasting, dancing, and the application of hallucinogens are all examples of the use of technology in order to reach various states of religious experience." The use of modern communication and media technology and other electronic devices, mainly by charismatic megachurches is a well-known phenomenon (see Jackelén 2005:869). On a more macabre note we know that technology also serves the cause of religious fanatics, as evidenced by suicide bombings, and it is not impossible that religious differences may yet trigger a third world war.

\section{SECULAR SPIRITUALITY A MODEL FOR A POSTMODERN NATURAL THEOLOGY}

The science and religion debate is marked by efforts to make room for God in a closed worldview, in which secular science - along with the constraints of empirical observation, scientific methodology and causal connections - dictate the rules. But even the few loopholes left for divine action in the secular domain of nature are disputed. Known instances of natural phenomena which are seen to allow scope for divine action are quantum mechanics (Bohm), autopoeitic cell systems in biology (Luhman), electromagnetism (A Fagg), supervenient theories of mind (Murphey), the design principle (Dembski, Behe), and the many examples of fine-tuning in the anthropic principle (Peacocke). But they fail to convince and are questioned by the view that God voluntarily limits himself and submits to the natural principles and laws that he laid down.

New Age spirituality has many elements suggestive of a revival of natural theology, yet it is not the same. Traditional natural theology can be traced to Aquinas's attempts to naturalise theology in the same way that Aristotle managed to rationalise the universe. Aquinas's natural theology produced the famous proofs of God's existence, which have at best ornamental value. William of Occam deconstructed that theology in light of God's limitless power and sovereignty - a strategy Karl Barth eventually applied to Brunner and all other attempts at natural theology (see Walach 2005:288).

The problem with relativising natural theology by invoking absolutes of faith, revelation, divine sovereignty or whatever is that it does not account for the relations between faith and rationality, nature and supernature, science 
and religion and, ultimately, church and the world. Thus it leaves believers with a paradoxical worldview. While it might still have been feasible in Aquinas's day, maybe even in Barth's, the pervasive influence of technoscience in our time is simply too overwhelming a threat for theology to ignore. That is evident from the amount of literature on the subject. What I have written shows that our life is so intertwined with technoscience, which in its turn is so integrally part of nature, that nature's role and its influence on our faith and thinking can hardly be overestimated. In fact, people are more aware of the interrelationship and interdependence of nature and human life than ever before. Theological ethics cannot pronounce from a transcendent height on all sorts of issues without acknowledging the inputs of medical science, socio-biology, and the cognitive and neuro-sciences.

Theologians and scientists alike, irrespective of the claims made by their respective disciplines, are restricted to human cognitive powers and the limits of provability. God's existence cannot be proved. But he can feature meaningfully in present-day worldviews if we connect the various aspects of our lives, our naive faith and our confined rationality, our neutral science and tainted ethics. Although many people seek and find God in nature, it does not mean that spirituality is returning to nature in the Rousseau's romantic sense. Neither is it a matter of inferring proofs of God's existence from nature, as Aquinas did. Instead it is a case of deepening human self-understanding through contact with nature and the natural sciences. There can be no true self-knowledge without knowledge of nature.

The term "secular spirituality" fulfils such a bridging function, indicating the mutual influencing between the technoscientific and spiritual spheres. "Naturalistic belief-systems, however well grounded in science, simply cannot compete with super-naturalist religion when it comes to the provision of credible compensators for such rewards. Hence the failure of belief-systems such as scientific humanism and Marxism-Leninism to appeal to more than a few intellectuals" (Aldridge 2000:96).

At the level of natural theology secular spirituality serves as a bridge between faith and reason, nature and grace, science and theology, nature and supernature. Its hallmark is humility - the humility of informed ignorance (docta ignorantia), of the limitation of human power and the relativisation of religious absolutes. It is the link between God's kenosis (self-emptying) and human kenosis. It is human beings" emulation, as images of God, of his voluntary self-limitation. Just as God submits himself to the laws he laid down, so humans curb isolating, alienating rational and religious absolutes. One characteristic of the kenosis of a king who becomes a servant is koinonia - 
fellowship ${ }^{18}$ with sufferers. Kenosis of religion leads to interaction with science and kenosis of science to interaction with every dimension of humanness. That is postmodern holism, which brings us one step closer to human integrity.

\section{Works consulted}

Aldridge, A 2000. Religion in the contemporary world: A sociological introduction. Cambridge: Polity.

Altmann, S L 2002. Is nature supernatural? A philosophical exploration of science and nature. New York: Prometheus.

Armstrong, T 2003. Technology: Multiplied man, in Bradshaw, D (ed), A concise companion to modernism, 158-178. Malden: Blackwell.

Aupers, S \& Houtman, D 2005. Reality sucks: On alienation and cybergnosis, in Borgman, E, Van Erp, S \& Haker, H (eds), Cyberspace - cyberethics cybertheology, 81-90. London: SCM.

Barrow, J D 1988. The world within the world. Oxford: Clarendon.

Boyer, $\mathrm{P}$ 1994. The naturalness of religious ideas: A cognitive theory of religion. Berkeley, CA: University of California

Boyer, P 2001. Religion explained: The evolutionary origins of religious thought. New York: Basic.

Bronislaw, S 2005. Rethinking the secular: Science, technology, and religion today. Zygon 40(4), 813-822.

Brown, W S, Murphy, N \& Malony, N H (eds) 1998. Whatever happened to the soul?: Scientific and theological portraits of human nature. Minneapolis, MN: Fortress.

Caiazza, J C 2005. Athens, Jerusalem, and the arrival of techno-secularism. Zygon 40(1), 9-21.

Colins, P 1999. Spirituality for the 21st century. Blackrock: Columbia.

Crossby, D A 2003. Naturalism as a form of religious naturalism. Zygon 38(1), 117120.

D'Aquili, E \& Newberg, A B 1999. The mystical mind: Probing the biology of religious experience. Minneapolis, MN: Fortress.

Dembski, W A 2001. What every theologian should know about creation, evolution and design, in Dembski, W A \& Richards, J W (eds), Unapologetic apologetics, 221-238. Downers Grove, IL: IVP.

Dershowitz, A 2004. Rights from wrongs: A secular theory of the origin of rights. New York: Basic.

Ducheyne, S 2006. Newton's secularized onto-theology versus Descartes and Leibniz, or on the importance of unifying tendencies in the secularizationprocess. Theology and Science 4(1), 71-86.

Du Toit C W 2004. Technoscience and the integrity of personhood in Africa and in the West: Facing our technoscientific environment, in Du Toit C W (ed), The integrity of the human person in an African context, 1-46. Pretoria: Unisa.

\footnotetext{
${ }^{18}$ In this regard Griffin (1988:15) writes: “... the modern desire to master and possess is replaced in postmodern spirituality with a joy in communion and a desire for letting-be."
} 
Fukuyama, F 2002. Our posthuman future: Consequences of the biotechnological revolution. London: Profile.

Glynn, P 1997. God. The evidence: Reconciliation of faith and reason in a postsecular world. USA (no city mentioned): Forum.

Grassow, M 1991. Spirituality and the struggle, in Worship, M \& Van der Water, D (eds), We shall overcome: Spirituality for liberation, 52-58. Pietermaritzburg: Cluster.

Griffin, D R (ed) 1988. Spirituality and society: Postmodern visions. New York: State university of New York.

Griffin, D R 2000. Religion and scientific naturalism: Overcoming the conflicts. New York: State university of New York.

Hefner, P 2003. Religion in the context of culture, theology, and global ethics. Zygon 38(1), 185-195.

Holland J 1988. A postmodern vision of spirituality and society, in Griffin, D R (ed), Spirituality and society: Postmodern visions, 41-62. New York: State University of New York.

Jackelén, A 2005. What is "secular"?: Techno-secularism and spirituality. Zygon 40(4), 863-873.

Lakoff, G A \& Johnson, M 1999. Philosophy in the flesh: The embodied mind and its challenge to Western thought. New York: Basic Books.

Luhman, N 1982. The world as society and as a social system. International Journal of General Systems 8, 131-138.

McGrath, A 1999. Christian spirituality. Malden: Blackwell.

McGrath, A 2001. A scientific theology, vol 1, Nature. Edinburgh: T \& T Clark.

Miller, R 1995. Arguments against secular culture. London: SCM.

Monod, J 1971. Chance and necessity: An essay on the natural philosophy of modern biology. New York: Knopf.

Murphy, N 1989. Human nature: Historical, scientific, and religious issues, in Brown, W S et al (eds), Whatever to the soul? 1-30. Minneapolis, MN: Fortress.

Newberg, A B \& d'Aquili, E G 2000. The creative brain/The creative mind. Zygon 35(1), 53-68.

Newman, J 1997. Religion and technology: A study in the philosophy of culture. Westport: Praeger.

Pannenberg, W 1988. Christianity in a secularized world. London: SCM.

Paris, P J 1995. The spirituality of African peoples: The search for a common moral discourse. Minneapolis, MN: Fortress.

Peacock, A R 1993. Theology for a scientific age: Being and becoming - natural, divine and human. Minneapolis, MN: Fortress.

Peters, T 2005. Techno-secularism, religion, and the created co-creator. Zygon 40(4), 845-862.

Peterson, G R 2005. Forty years later: What have we accomplished? Zygon 40(4), 875-890.

Raman, V V 2005. Religions in a secular world. Theology and Science 3(1), 3-4.

Raman, V V 2005b. Techno-secularism: Comments and reflections. Zygon 40(4), 823-834.

Rolston III, H. 1996. Scientific inquiry, in Van Ness, P, H (ed), Spirituality and the secular quest, 387-413. New York: Crossroad.

Roy, R 2005. Scientism and technology as religion. Zygon 40(4), 835-844. 
Shermer, M 2004. The science of good and evil. New York: Owl.

Walach, H 2005. Reconciling spirituality and science in the twenty-first century: Elements for a world view incorporating spiritual and scientific insights. Studies in Spirituality 15, 283-308.

Wiersenga, H 1992. Geloven bij daglicht: Verlies en toekomst van een traditie. Amsterdam: Ten Have.

Whitworth, M H 2003. Physics: "A strange footprint", in Bradshaw, D (ed), A concise companion to modernism, 200-220. Malden: Blackwell.

Worsnip, M \& Van der Water, D 1991. We shall overcome: Spirituality for liberation, 52-58. Pietermaritzburg: Cluster.

Wuketits, F M 1984. Concepts and approaches in evolutionary epistemology: Toward an evolutionary theory of knowledge. Dordrecht: Reidel. 